invades surrounding structures such as the heart, lungs, pleura, and superior vena cava $[1,2]$. Patients often present with cough, dyspnea, chest pain, and superior vena cava syndrome [3]. $\mathrm{R}-\mathrm{CHOP}$ plus consolidative mediastinal radiation is often an option [4]. Herein, we report a rare case of asymptomatic PMBCL with bulky mediastinal mass in which the patient achieved complete remission after R-CHOP and mediastinal radiation.

Keywords: Mediastinal neoplasm, B-cell lymphoma, PMBCL

Anahtar Sözcükler: Mediastinal kitle, B hücreli lenfoma, PMBCL

Conflict of Interest: The authors of this paper have no conflicts of interest, including specific financial interests, relationships, and/or affiliations relevant to the subject matter or materials included.

\section{References}

1. Savage KJ. Primary mediastinal large B-cell lymphoma. Oncologist 2006;11:488-495.

2. Bhatt VR, Mourya R, Shrestha R, Armitage J0. Primary mediastinal large B-cell lymphoma. Cancer Treat Rev 2015;41:476-485.

3. Abou-Elella AA, Weisenburger DD, Vose JM, Kollath JP, Lynch JC, Bast MA, Bierman PJ, Greiner TC, Chan WC, Armitage JO. Primary mediastinal large B-cell lymphoma: a clinicopathologic study of 43 patients from the Nebraska Lymphoma Study Group. J Clin Oncol 1999;17:784-790.

4. Giri S, Bhatt VR, Pathak R, Bociek RG, Vose JM, Armitage JO. Role of radiation therapy in primary mediastinal large B-cell lymphoma in rituximab era: a US population-based analysis. Am J Hematol 2015;90:1052-1054.

${ }^{\circ}$ Copyright 2018 by Turkish Society of Hematology

Turkish Journal of Hematology, Published by Galenos Publishing House

\title{
A Rare Late Complication of Port Catheter Implantation: Embolization of the Catheter
}

Nadir Görülen Bir Port Kateter Geç Komplikasyonu: Kateter Embolizasyonu

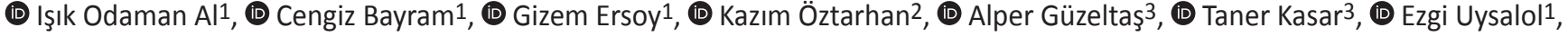 \\ (D) Başak Koç¹, (D) Ali Ayçiçek¹, (D) Nihal Özdemir1 \\ 1 University of Health Sciences, Istanbul Kanuni Sultan Süleyman Training and Research Hospital, Clinic of Pediatric Hematology and Oncology, \\ istanbul, Turkey \\ 2 University of Health Sciences, Istanbul Kanuni Sultan Süleyman Training and Research Hospital, Clinic of Pediatric Cardiology, Istanbul, Turkey \\ 3 University of Health Sciences, Istanbul Mehmet Akif Ersoy Thoracic and Cardiovascular Surgery Training and Research Hospital, Clinic Pediatric \\ Cardiology, İstanbul, Turkey
}

\section{To the Editor,}

Children with cancer need long-term venous access due to the long duration of therapy. Long-term totally implantable port devices (TIPDs) are widely used in these patients for administration of chemotherapeutic agents, parenteral nutrition, fluids, and blood products [1,2]. Fracture and embolism of TIPDs are rare complications but may cause serious results and mortality, including pulmonary artery embolism, sepsis, arrhythmias, and perforation of the caval vein $[3,4,5]$. Herein, we present a 9 -yearold male patient with pre-B acute lymphoblastic leukemia who was admitted to the outpatient pediatric hematology and oncology clinic at the $13^{\text {th }}$ month of maintenance therapy due to new onset of non-flushing catheter. The patient had no other complaints. On posterior anterior chest $\mathrm{X}$-ray, the catheter was found to be disconnected from its reservoir (Figure 1). Echocardiography

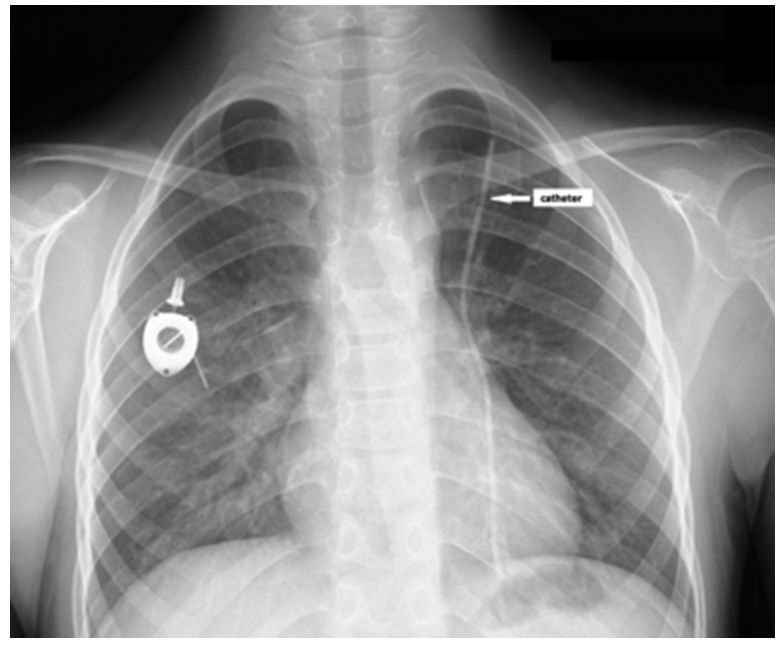

Figure 1. Chest $\mathrm{X}$-ray showing disconnection of the catheter from its reservoir. 
and thorax computed tomography angiography of the patient revealed the embolization of the catheter to the left pulmonary artery (Figure 2). The embolized catheter was removed using an interventional endovascular procedure under general anesthesia through the femoral vein by an interventional cardiologist (Figure 3). Our case report highlights a rarely encountered complication of TIPDs, which may be undiagnosed due to its rarity and lack of symptoms in some patients, leading to serious complications.

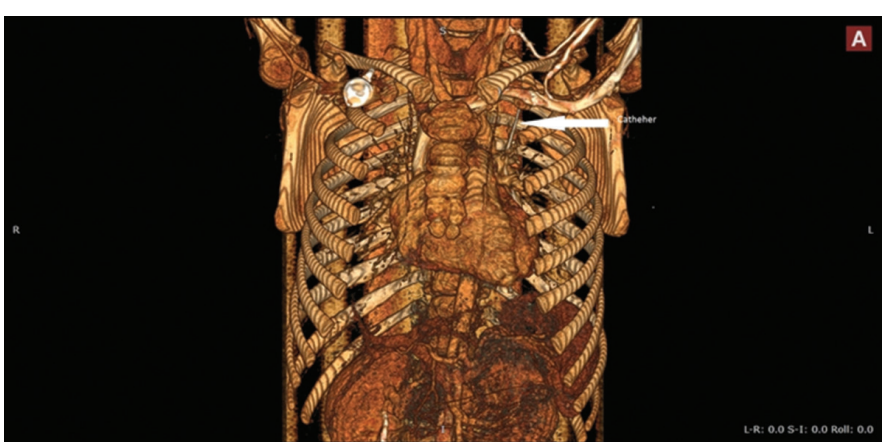

Figure 2. Thorax computed tomography angiography of the patient showing the embolization of the catheter to the left pulmonary artery.

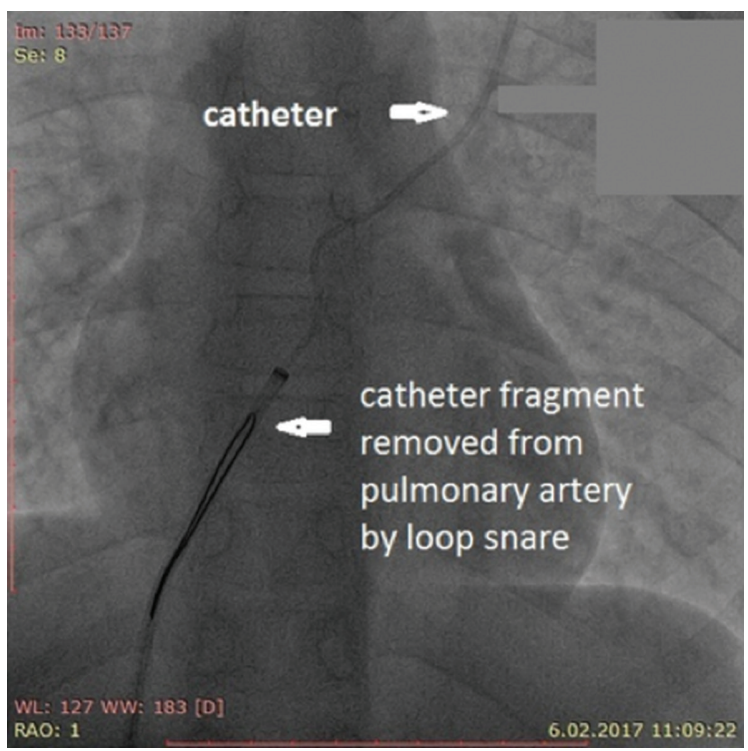

Figure 3. Removal of the catheter with an interventional endovascular procedure from pulmonary artery.
Keywords: Acute lymphoblastic leukemia, Catheter, Complication

Anahtar Sözcükler: Akut lenfoblastik lösemi, Kateter, Komplikasyon

Conflict of Interest: The authors of this paper have no conflicts of interest, including specific financial interests, relationships, and/or affiliations relevant to the subject matter or materials included.

\section{References}

1. Kurul S, Saip P, Aydin T. Totally implantable venous-access ports: local problems and extravasation injury. Lancet Oncol 2002;3:684-692.

2. Intagliata $E$, Basile $F$, Vecchio R. Totally implantable catheter migration and its percutaneous retrieval: case report and review of the literature. G Chir 2017;37:211-215.

3. Kassar O, Hammemi R, Ben Dhaou M, Kammoun S, Elloumi M. Spontaneous fracture and migration of a totally implanted port device to pulmonary artery in acute leukemia child. J Pediatr Hematol Oncol 2017;39:103-105.

4. Surov A, Buerke $M$, John E, Kösling $S$, Spielmann RP, Behrmann C. Intravenous port catheter embolization: mechanisms, clinical features, and management. Angiology 2008;59:90-97.

5. Ribeiro RC, Monteiro AC, Menezes OC, Schettini ST, Vianna SM. Totally implantable catheter embolism: two related cases. Sao Paulo Med J 2008;126:347-349.
Address for Correspondence/Yazışma Adresi: Cengiz BAYRAM M.D.,

University of Health Sciences, İstanbul Kanuni Sultan Süleyman Training and Research Hospital,

Clinic of Pediatric Hematology and Oncology, İstanbul, Turkey

Phone : +905058396092

E-mail : cengizbayram2013@gmail.com ORCID-ID: orcid.org/0000-0003-2153-0628
Received/Geliş tarihi: March 30, 2017 Accepted/Kabul tarihi: April 20, 2017

DOI: $10.4274 /$ tjh.2017.0134 